Bangladesh J. Sci. Res. 29(2): 89-99, 2016 (December)

\title{
BIOACCUMULATION OF HEAVY METALS IN NILE TILAPIA OREOCHROMIS NILOTICUS (LINNAEUS 1758) FED WITH COMMERCIAL FISH FEEDS
}

\author{
Md. Iqbal Hossain, Badhan Saha ${ }^{1}$, Mahmuda Begum ${ }^{1}$, Nusrat Jahan Punom, \\ Mst. Khadiza Begum and Mohammad Shamsur Rahman* \\ Department of Fisheries, Faculty of Biological Sciences, University of Dhaka, \\ Dhaka-1000, Bangladesh
}

\begin{abstract}
The study was carried out to determine the concentration of heavy metals in some commonly used commercial fish feeds and to observe the bioaccumulation of $\mathrm{Cr}, \mathrm{Cu}, \mathrm{Cd}$ and $\mathrm{Ni}$ in liver, muscle and gills of tilapia Oreochromis niloticus after culturing them for 60 days by feeding those commercial feeds. The study revealed that the concentration of $\mathrm{Cu}$ was the highest $(65.08 \mathrm{mg} / \mathrm{kg})$ in handmade feed (B1) among four heavy metals. The concentrations of $\mathrm{Cr}$ in collected feeds were 1.75 to $3.04 \mathrm{mg} / \mathrm{kg}$, which exceeds the permissible limit set by FAO. In cultured tilapia, the concentrations of studied heavy metals were found higher than initial concentration in fish feeds and in tilapia fingerlings. Metal levels in cultured fish followed the ranking of $\mathrm{Cu}>\mathrm{Cr}>\mathrm{Ni}>\mathrm{Cd}$ and order in individual organs was liver>gill>muscle. The highest concentration of $\mathrm{Cu}(72.86 \mathrm{mg} / \mathrm{kg})$ was found in liver given S feed and the lowest concentration $(0.67 \mathrm{mg} / \mathrm{kg})$ was in muscle receiving Q feed. Bioaccumulation of $\mathrm{Cr}$ was the highest $(23.95 \mathrm{mg} / \mathrm{kg})$ in liver taken B1 feed and the lowest $(9.29 \mathrm{mg} / \mathrm{kg})$ in muscle of tilapia cultured with $\mathrm{C}$ feed. Concentration of $\mathrm{Cu}$ exceeded the tolerable limit in fishes cultured with $\mathrm{S}$ and $\mathrm{C}$ feeds. But $\mathrm{Cr}$ concentration surpassed the allowable limit in every feed studied. The concentrations of $\mathrm{Ni}$ and $\mathrm{Cd}$ were below the permissible range approved by FAO. Considering the present study, tilapia cultured with these experimental feeds is not safe for human consumption. Higher concentration of these heavy metals exceeding allowable limit may cause harmful effect on human body after consumption of those fishes and can create cancer and other diseases in human body.
\end{abstract}

Key words: Nile tilapia Oreochromis niloticus, heavy metals, bioaccumulation, fish feed

\section{Introduction}

'Heavy metals' is a general collective term, which applies to the group of metals and metalloids with atomic density greater than $5 \mathrm{~g} / \mathrm{cm}^{3}$ (Hawkes 1997). Heavy metals include lead $(\mathrm{Pb})$, cadmium (Cd), nickel (Ni), zinc ( $\mathrm{Zn})$, mercury ( $\mathrm{Hg}$ ), arsenic (As), silver (Ag), chromium (Cr), copper $(\mathrm{Cu})$, iron $(\mathrm{Fe})$ and the platinum $(\mathrm{Pt})$ group elements. Bioaccumulation refers to any accumulation of chemicals in biota resulting uptake, storage and sequestration of contaminants (Streit 1998). Heavy metal can be incorporated into food chains and absorbed by aquatic organisms to a level that may affect their physiological state. Fish are particularly vulnerable and heavily exposed to pollution because they cannot escape from the detrimental effects of pollutants as they are feeding and living in the aquatic environments (Saleh and Marie 2014). Fishes are one

*Author for correspondence: < shamsur@du.ac.bd>. ${ }^{1}$ Biological Research Division, Bangladesh Council for Scientific and Industrial Research (BCSIR), Dhaka-1205, Bangladesh. 
of the most important organisms in the aquatic food chain, which are very sensitive to heavy metals contamination. Various metals are accumulated in fish body in different amounts. These differences result from different affinity of metals to fish tissues, different uptake, deposition and excretion rates. Various species of fish from the same water body may accumulate different amounts of metals. High level of heavy metals has apparent lethal and chronic effects on fishes (Kotze et al. 1999). Thus, fish not only indicates the pollution status of aquatic ecosystem but have significant impact on the food web (Chi et al. 2007).

Accumulation of metals in various organs and tissues depends upon the way of exposure such as through diet or their elevated level in surrounding environment (Nussey 2000). Heavy metals exhibit different accumulation pattern in organs (Nussey 2000). Gills, liver and kidneys accumulate heavy metals in higher concentration in comparison to muscles, which exhibit lowest levels of metals accumulation (Wepener et al. 2001). Among different organs, liver accumulates higher concentrations of metals and has been used widely to investigate the process of bioaccumulation. Exchange of gases and absorption of heavy metals takes place from external aquatic to internal body environment through gills (Wepener et al. 2001).

Concentration of metals becomes toxic to the fish when its level exceeds the permissible level. This threshold limit not only varies from metal to metal but also from one species to another (Mansour and Sidky 2002). Toxic effects of metals become more pronounced when various metabolic activities inside the body of organism fail to detoxify. Consumption of contaminated fish with heavy metals can result hazardous effects on human health (Morais et al. 2012). Adverse effects of heavy metals may include serious threats like renal failure, liver damage, cardiovascular diseases and even death (Rahman et al. 2012).

Tilapia is one of the most important fish species and widely cultured in Bangladesh to meet the increased protein demand and due to its profitability. Tilapia farming is widespread in many other Asian countries including China, Indonesia, the Philippines, Thailand and Vietnam due to its rapid growth rate, high market demand and increasing consumer acceptance (ADB 2005). Many researchers have worked on the bioaccumulation of the heavy metals in tilapia collected from various sources all over the world and determined different heavy metal concentration accumulated from the environment the fish lived but in Bangladesh, there is no research regarding heavy metal bioaccumulation in tilapia by feeding commercial fish feeds.

Therefore, the study was aimed to determine the concentration of heavy metals in different commercial fish feeds and their bioaccumulation in fish body after culture of tilapia with those heavy metal contaminated feeds.

\section{Materials and Methods}

The study was carried out in two laboratories (Soil, Agronomy and Environment Section, and Zoology Section) of Bangladesh Council of Scientific and Industrial Research (BCSIR) in Dhaka, Bangladesh from September 2015 to January 2016. Tilapia fingerlings were collected in polythene 
bags with oxygenated water from Sotota Hatchery in Tarakanda, Mymensingh and transported to BCSIR, Dhaka.

Experimental feeds and their application: Five different types of experimental feeds were used in this research work. Three of them were commercial feeds ( $C$ feed, Q feed and S feed) collected from different hatcheries of Mymensingh district. Other two were handmade feeds (B1 and B2) prepared at Zoology Section, BCSIR. B1 was made from the mixer of rice bran, corn grain, wheat, shrimp grain, fish grain, oil cake, soybean, fat, vitamins and minerals and B2 was made by mixing corn grain, wheat, spirulina, shrimp grain, soybean, fat, vitamins and minerals.

Tilapia fingerlings were cultured for two months from November, 2015 to January, 2016 in glass aquaria of volume $\left(30 \times 14 \times 6\right.$ inch $\left.^{3}\right)$ at Zoology Section of BCSIR. Each aquarium was filled with 60 liters clean tap water and water was changed once in a week. The feeding trials were conducted in ten aquaria and groups of 20 tilapia fingerlings having similar body length and weight were selected and randomly stocked to each aquarium with a duplicate for each experimental diet. The fingerlings in each aquarium were fed once in a day at a fixed feeding rate. In first 20 days of the experiment, feeds were given at $10 \%$ of body weight, $5 \%$ in next 20 days and 3\% for the remaining experimental days. To supply adequate oxygen into the aquaria, aeration was done continuously by setting up aerator in each aquarium. Different water quality parameters e.g. dissolved oxygen, water temperature and $\mathrm{pH}$ were measured weekly.

Determination of heavy metals: To determine the initial concentration of heavy metals in collected fingerlings, whole sample was taken because fingerlings were too small. The samples were processed for heavy metal determination according to Huq and Alam (2005). At first $1 \mathrm{gm}$ of the feed samples was taken and $10 \mathrm{ml}$ nitric acid was mixed with the samples. Then the mixture was kept in the fume chamber and digested at $120^{\circ} \mathrm{C}$ for 6 hrs. The digested samples were diluted to $50 \mathrm{ml}$ with deionized water and the solution was filtered and collected into clean and sterilized plastic bottles. Then heavy metals $(\mathrm{Cr}, \mathrm{Cu}, \mathrm{Cd}$ and $\mathrm{Ni}$ ) were detected using Atomic Absorption Spectrometer (Model No.: AA-7000, Shimadzu). After 60 days culture, liver, gills and muscle samples were collected from the fishes and heavy metal concentration was determined using the same procedure. In case of heavy metal determination of fish feeds, the samples were not needed to be dried and sample preparation was same as fish sample preparation. Heavy metal was determined by using the following formula: Concentration of heavy metals $=$ (reading - blank reading) $\times \mathrm{PDF} \times \mathrm{SDF}$; where, primary dilution factor $(\mathrm{PDF})=$ Volume/weight of sample, and secondary dilution factor $(\mathrm{SDF})=$ Secondary volume/secondary weight of sample. Heavy metals concentrations were expressed as ppm (mg/kg).

\section{Results and Discussion}

Concentration of heavy metals in different fish feeds: Among different experimental feeds the concentration of $\mathrm{Cr}$ was recorded as $3.04 \mathrm{mg} / \mathrm{kg}$ in $\mathrm{Q}$ feed which was the highest. The lowest value of $\mathrm{Cr}(1.75 \mathrm{mg} / \mathrm{kg})$ was observed in $\mathrm{C}$ feed. The concentration of $\mathrm{Cr}$ in $\mathrm{S}$ feed was 2.43 $\mathrm{mg} / \mathrm{kg}$ (Fig. 1). According to FAO (1983) the acceptable limit of $\mathrm{Cr}$ is $1.0 \mathrm{mg} / \mathrm{kg}$. The results 
showed that the concentrations of $\mathrm{Cr}$ in all of the experimental feeds were above the acceptable limit.

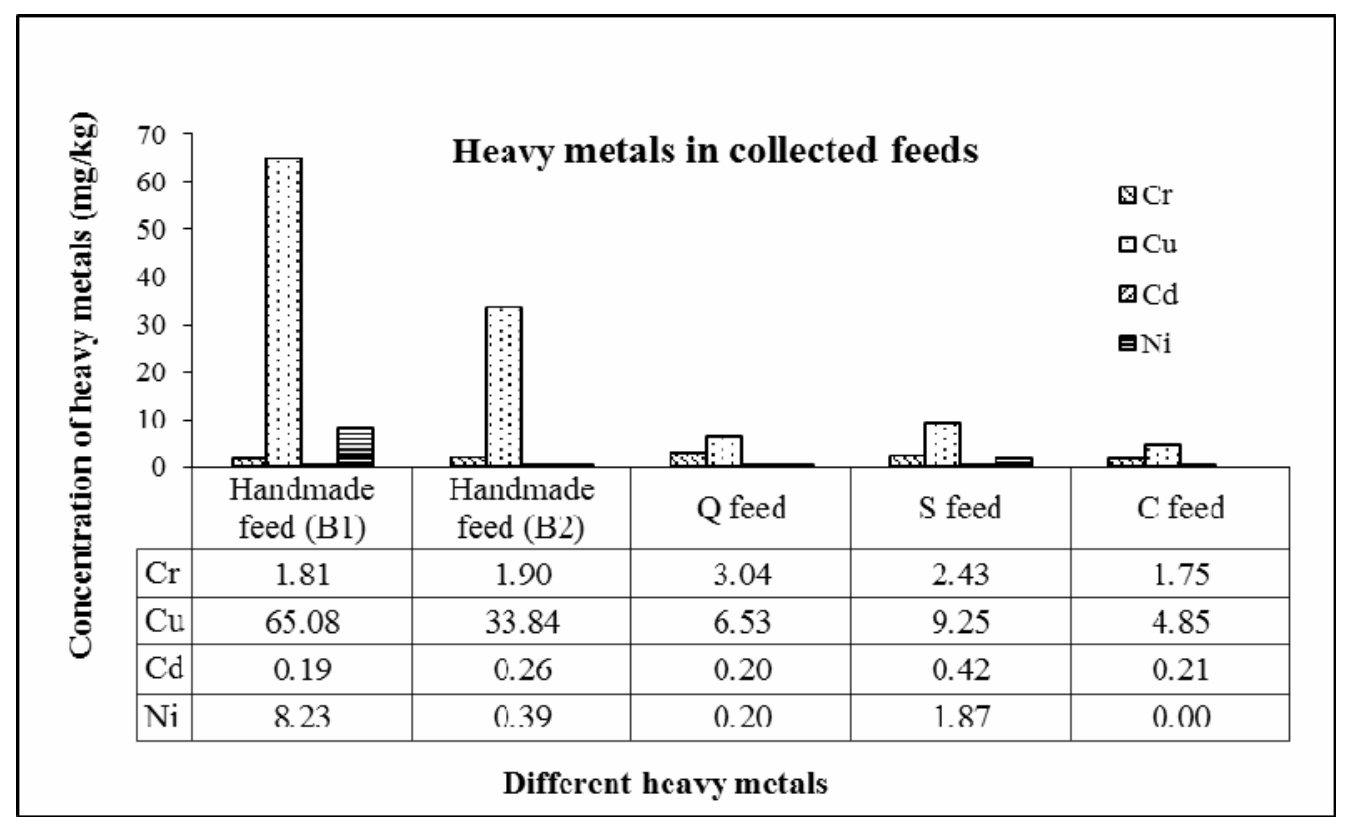

Fig. 1. Concentration of different heavy metals in collected sample of fish feeds.

The highest concentration of $\mathrm{Cu}(65.08 \mathrm{mg} / \mathrm{kg})$ was found in handmade feed (B1). The lowest concentration $(4.85 \mathrm{mg} / \mathrm{kg}) \mathrm{Cu}$ was recorded in $\mathrm{C}$ feed. The concentration of $\mathrm{Cu}$ in handmade feed (B2) was $33.84 \mathrm{mg} / \mathrm{kg}$ (Fig. 1). The allowable limit of concentration of $\mathrm{Cu}$ in a food ingredient is $30 \mathrm{mg} / \mathrm{kg}$ (FAO 1983). This study showed that the concentrations of $\mathrm{Cu}$ in two handmade feed were above the permissible limit.

The lowest concentration $(0.19 \mathrm{mg} / \mathrm{kg})$ of $\mathrm{Cd}$ was found in handmade feed (B1) and the highest concentration $(0.42 \mathrm{mg} / \mathrm{kg}$ ) was found in S feed (Fig. 1). The permissible Cd concentration in feed ingredients of plant origin is $1 \mathrm{mg} / \mathrm{kg}$, and in those of animal origin $2 \mathrm{mg} / \mathrm{kg}$ (FAO 1983). Therefore, from this study we can say that the concentration of $\mathrm{Cd}$ was within the acceptable limit.

The highest concentration of $\mathrm{Ni}$ was found to be $8.23 \mathrm{mg} / \mathrm{kg}$ in handmade feed (B1) and the lowest was observed in $\mathrm{C}$ feed which was below detection level. In $\mathrm{S}$ feed, the value of $\mathrm{Ni}$ was recorded as $1.87 \mathrm{mg} / \mathrm{kg}$ (Fig. 1). In the current regulations there are no maximum allowed concentrations of nickel for feed ingredients and compound feed. The limits for the allowed nickel content in different human foods range between 0.1 and $8 \mathrm{mg} / \mathrm{kg}$ (Alexieva et al. 2007). So the recorded data for concentration of $\mathrm{Ni}$ in feed materials and compound feeds are not appalling except handmade feed (B1), if compared to acceptable nickel content in human food. 
The results showed that there had been noticeable amount of different heavy metals in fish feeds. The concentrations of $\mathrm{Cr}$ and Ni were higher than other heavy metals. In Bangladesh, it has been accounted that the tannery solid wastes are changed to protein concentrate to be used as fish feed, poultry feed, and in production of organic fertilizers. It is a common phenomenon in the largest tanning area of the country for over the last several years at Hazaribagh tannery area at the south-eastern part of Dhaka city. One of the major concerns of this activity is the heavy metals, especially chromium, used in the tanning processes (Hossain et al. 2007).

Concentration of heavy metals in tilapia: Initial concentration of different heavy metals in collected tilapia fingerlings (pooled sample) was determined. Among different heavy metals in tilapia fingerlings, the concentration of $\mathrm{Cu}$ was found to be the highest $(13.79 \mathrm{mg} / \mathrm{kg})$ followed by $\mathrm{Cr}$ and $\mathrm{Cd}$. The concentration of Ni was found below detection limit (BDL) (Fig. 2).

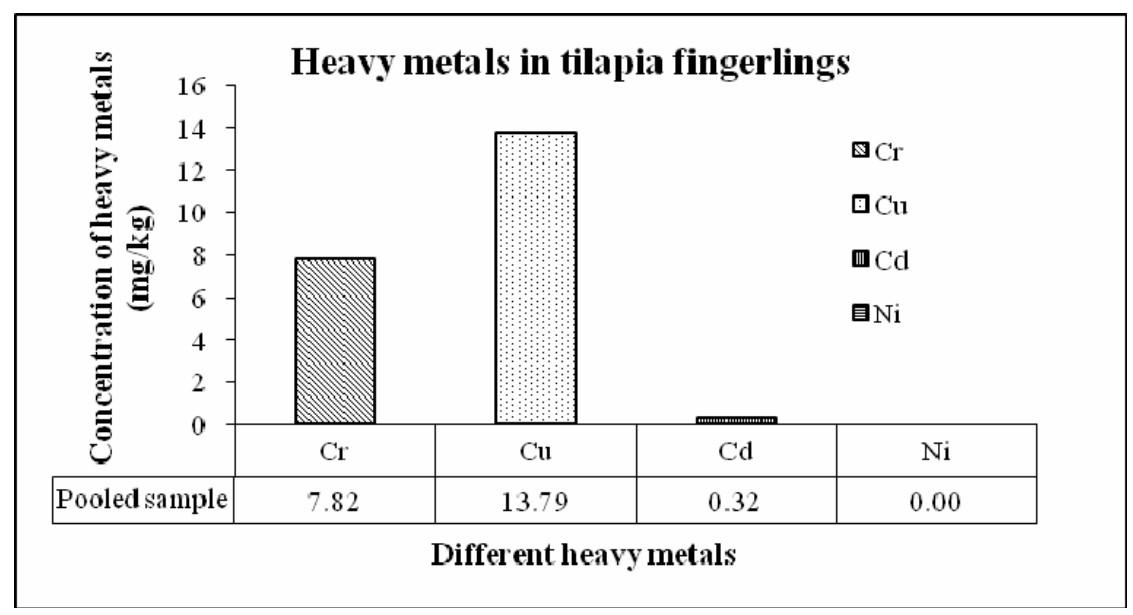

Fig. 2. Concentration of different heavy metals in tilapia fingerlings.

After 60 days culture period, concentration of various heavy metals in different organs (liver, gills and muscle) were also measured.

The concentration of $\mathrm{Cr}$ in liver was found to be the highest in T1 (handmade feed, B1) and the lowest in T4 (S feed); concentrations of $\mathrm{Cr}$ in gills were the highest and the lowest in B1 feed and $\mathrm{C}$ feed, respectively; in muscle the highest and the lowest values were found in B1 feed and handmade feed (B2) and C feed, respectively (Fig. 3). Abdel-Baki et al. (2011) reported that the average concentration of $\mathrm{Cr}$ in different tilapia fish organs, liver, gills, muscles and kidney were $0.328,0.386,0.230$ and $0.512 \mathrm{ppm}$, respectively. This study indicates that the kidney accumulated the highest concentration of $\mathrm{Cr}$ whereas muscles accumulated the lowest concentration.

After 60 days of culture, the concentration of $\mathrm{Cu}$ in liver was found to be the highest in $\mathrm{S}$ feed and lowest in handmade feed B2. The highest concentration of $\mathrm{Cu}$ was observed in gills of tilapia receiving handmade feed (B1) and the lowest in Q feed treatment. The highest concentration of $\mathrm{Cu}$ in muscle was found in fishes given S feed and lowest in Q feed (Fig. 4). Abdel-Baki et al. (2011) 
found the average concentrations of $\mathrm{Cu}$ were 11.533, 2.060, 1.080 and $7.990 \mathrm{ppm}$ in tilapia ( $T$. nilotica) liver, gills, muscles and kidney, respectively. These data showed that, liver accumulated the highest concentration while muscles accumulated the lowest.

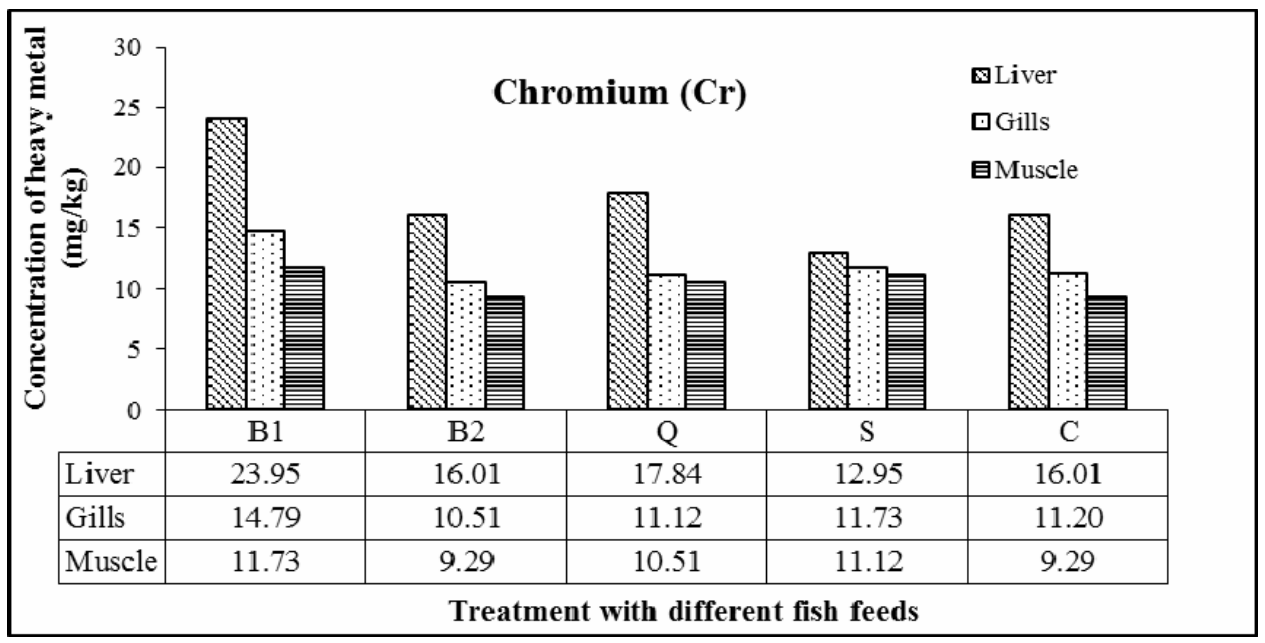

Fig. 3. Concentration of chromium in different organs of cultured tilapia in five treatments.

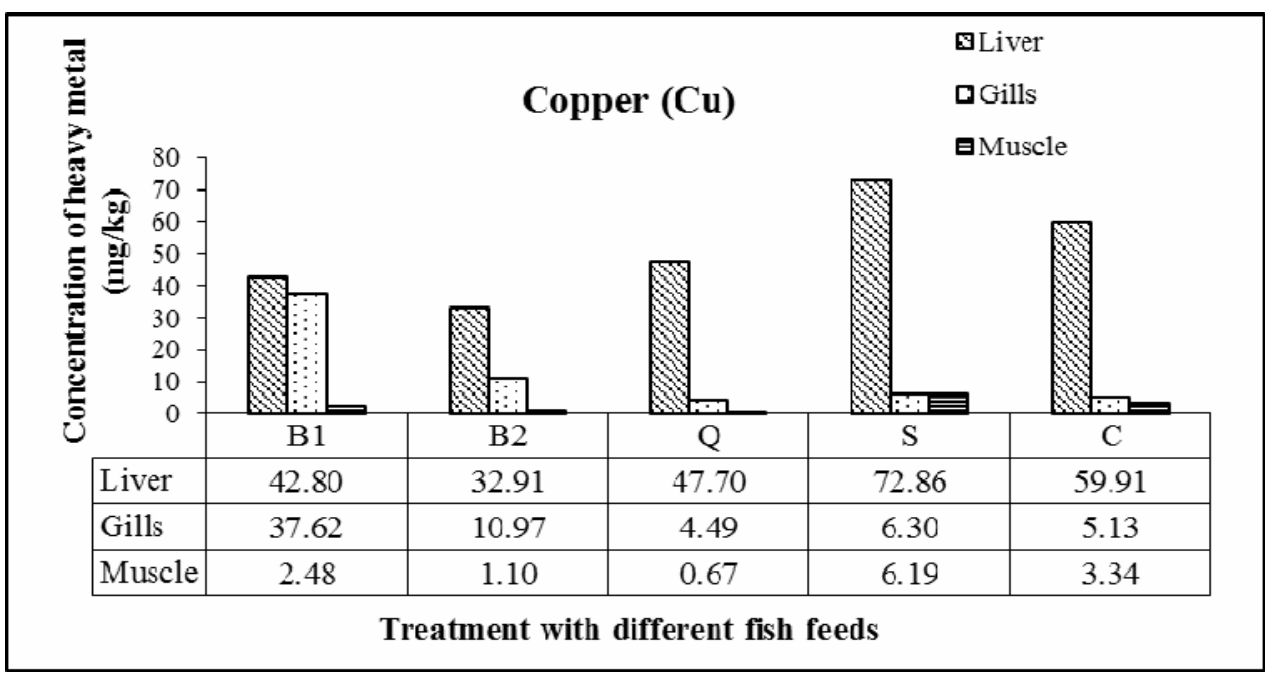

Fig. 4. Concentration of copper in different organs of cultured tilapia in five treatments.

Fig. 5 shows that the concentration of cadmium in liver was found to be the highest in B1 feed, and in B2, quality and C feed the concentration of Cd was below detection level. A study on T. nilotica reported that the mean Cd concentrations were $0.0151 \mathrm{ppm}$ in liver, $0.0099 \mathrm{ppm}$ in gills, $0.0075 \mathrm{ppm}$ in muscles and $0.0078 \mathrm{ppm}$ in kidney (Abdel-Baki et al. 2011). The data 
revealed that the liver accumulated the highest concentration of Cd while muscles accumulated the lowest.

The highest concentration of $\mathrm{Ni}$ in liver was found in handmade feed (B1) and the lowest was found in C feed. Ni concentration in gills was comparatively higher in different treatments. The highest concentration of $\mathrm{Ni}$ in gills was observed in fishes receiving B1 feed and lowest in fishes receiving $\mathrm{C}$ feed (Fig. 6).

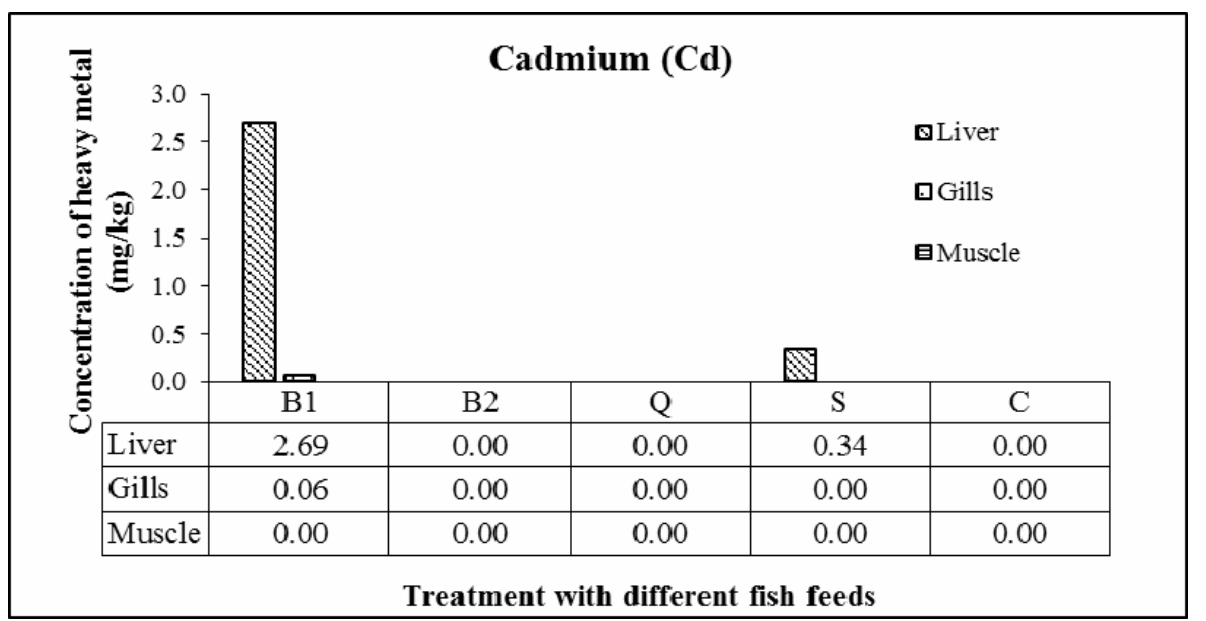

Fig. 5. Concentration of cadmium in different organs of cultured tilapia in five different treatments.

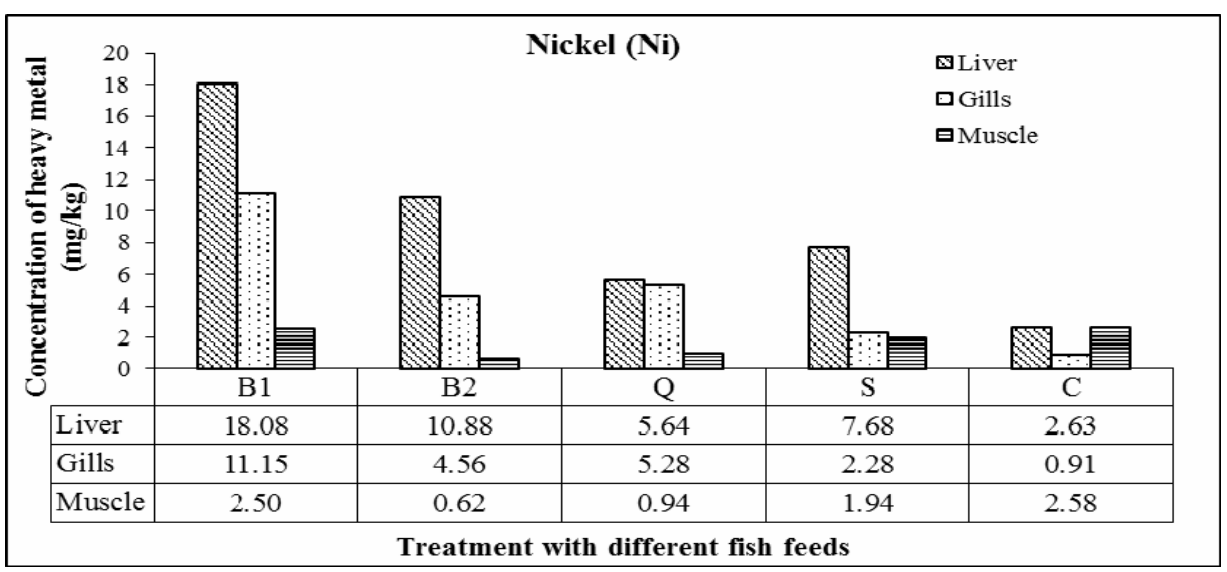

Fig. 6. Concentration of nickel in different organs of cultured tilapia in five different treatments.

Mohamed (2008) reported that the metals were accumulated in different tissues of $O$. niloticus and Lates niloticus by various levels, where, the non-edible parts accumulated more metals than the edible muscles. In this study heavy metals were also accumulated in muscles at lower levels than in liver of cultured O. niloticus. 
Bioaccumulation of heavy metals: Bioaccumulation of different heavy metals in cultured tilapia was compared to five different experimental fish feeds and with initial heavy metal concentrations in tilapia fingerlings. These comparisons are described through Figs. 7 to 11.

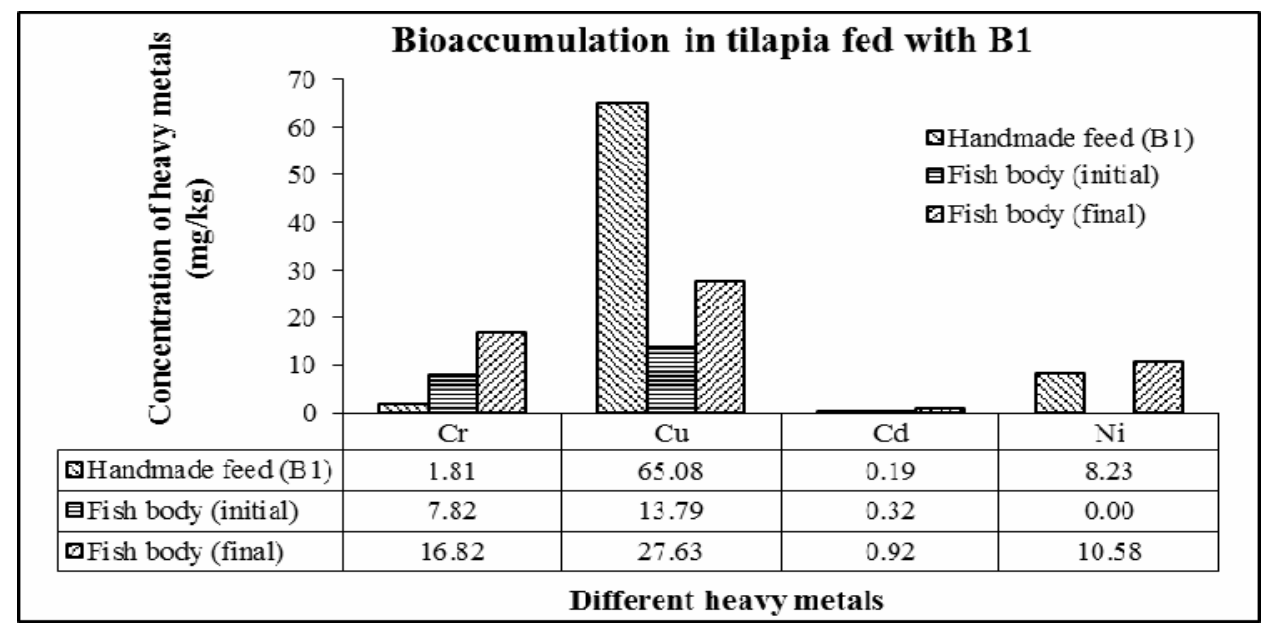

Fig. 7. Comparison of different heavy metals among handmade feed (B1), tilapia fingerlings and cultured tilapia fed on B1 feed.

Fig. 7 indicates that the concentration of $\mathrm{Cr}$ was higher in cultured tilapia receiving $\mathrm{B} 1$ feed (T1) than initial concentration of $\mathrm{Cr}$ in feed and fingerling sample whereas concentration of $\mathrm{Cu}$ was decreased in final fish body. The concentration of Ni was also increased in cultured fish (Fig. 7).

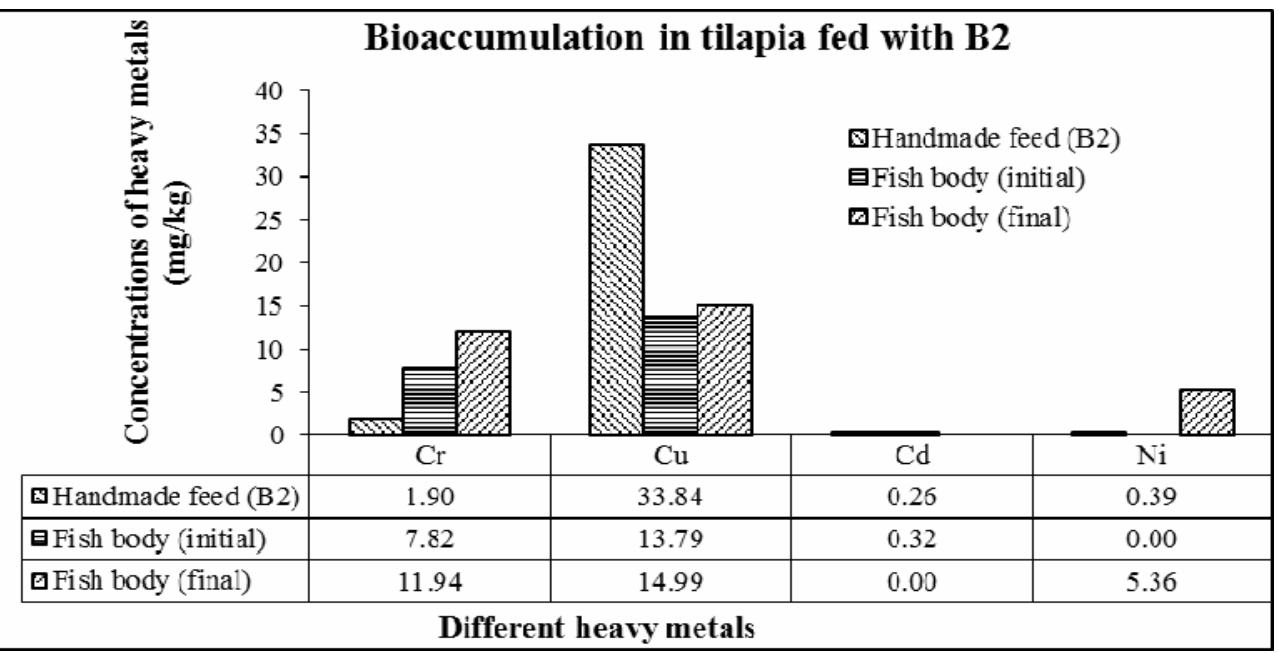

Fig. 8. Comparison of different heavy metals among handmade feed (B2), tilapia fingerling and cultured tilapia fed on B2 feed. 
From Fig. 8 it can be said that the concentration of $\mathrm{Cr}$ and $\mathrm{Ni}$ were increased noticeably in cultured tilapia given handmade feed B2, where concentration of $\mathrm{Cu}$ was decreased in cultured fish.

The concentrations of $\mathrm{Cr}$ and $\mathrm{Ni}$ were higher in cultured fish than feed and fingerlings of tilapia fed on $\mathrm{Q}$ feed. In this case the concentration of $\mathrm{Cu}$ was found significantly higher in cultured tilapia (Fig. 9).

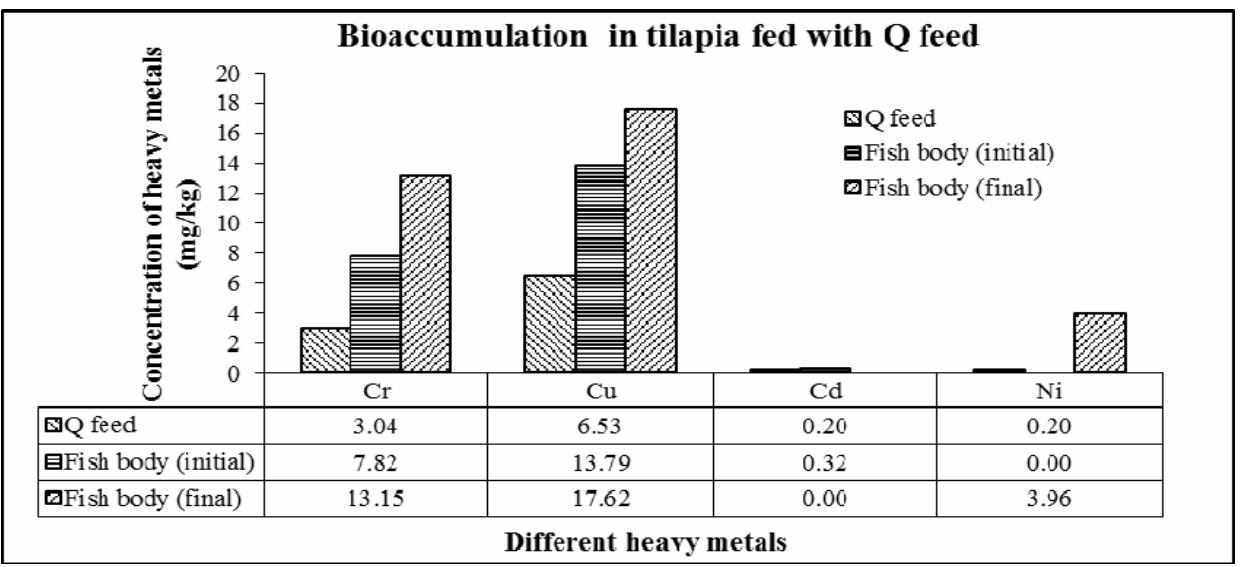

Fig. 9. Comparison of different heavy metals among Q feed, tilapia fingerlings and cultured tilapia fed on Q feed.

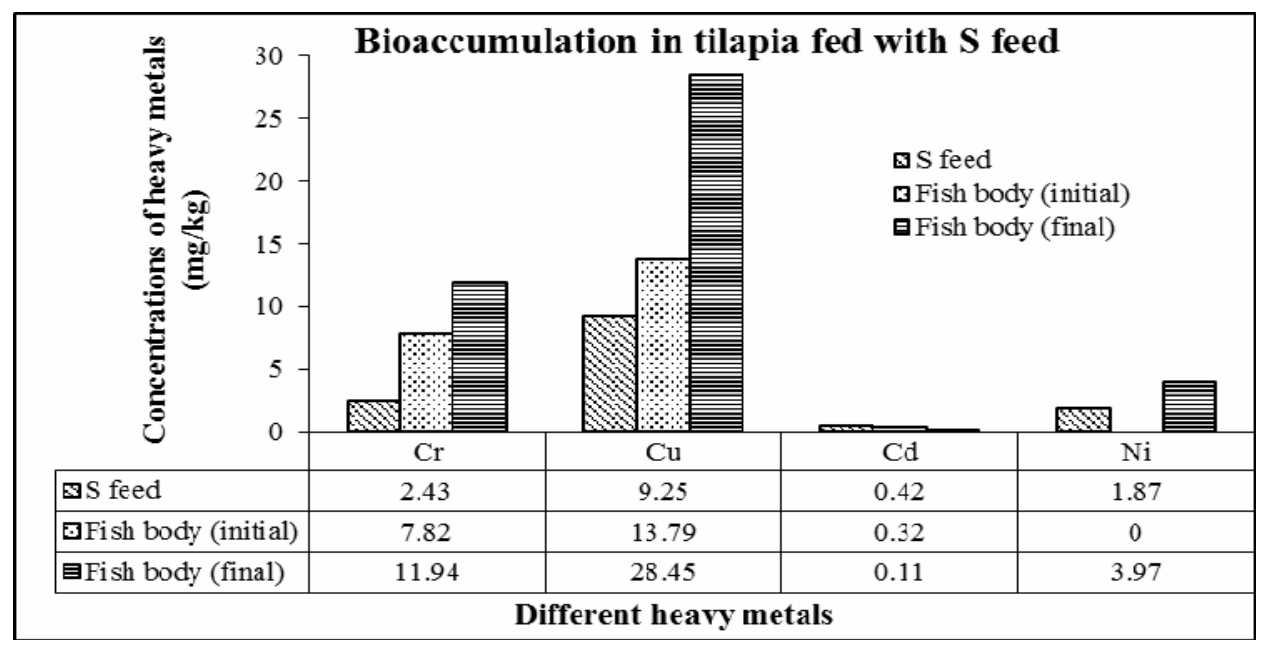

Fig. 10. Comparison of different heavy metals among $\mathrm{S}$ feed, tilapia fingerling and cultured tilapia fed on S feed.

In case of $\mathrm{S}$ feed treatment, concentration of $\mathrm{Cr}, \mathrm{Cu}$ and $\mathrm{Ni}$ was higher in cultured tilapia than feed and tilapia fingerlings. 
Cultured tilapia fed on $\mathrm{C}$ feed contained higher amount of $\mathrm{Cr}, \mathrm{Cu}$ and $\mathrm{Ni}$ in their tissue than initial concentration of those metals in the feed and fingerlings. In case of $\mathrm{Ni}$, though the initial concentrations of $\mathrm{Ni}$ in collected feed and fingerling samples were below detection limit but in cultured fish the amount was noticeable (Fig. 11).

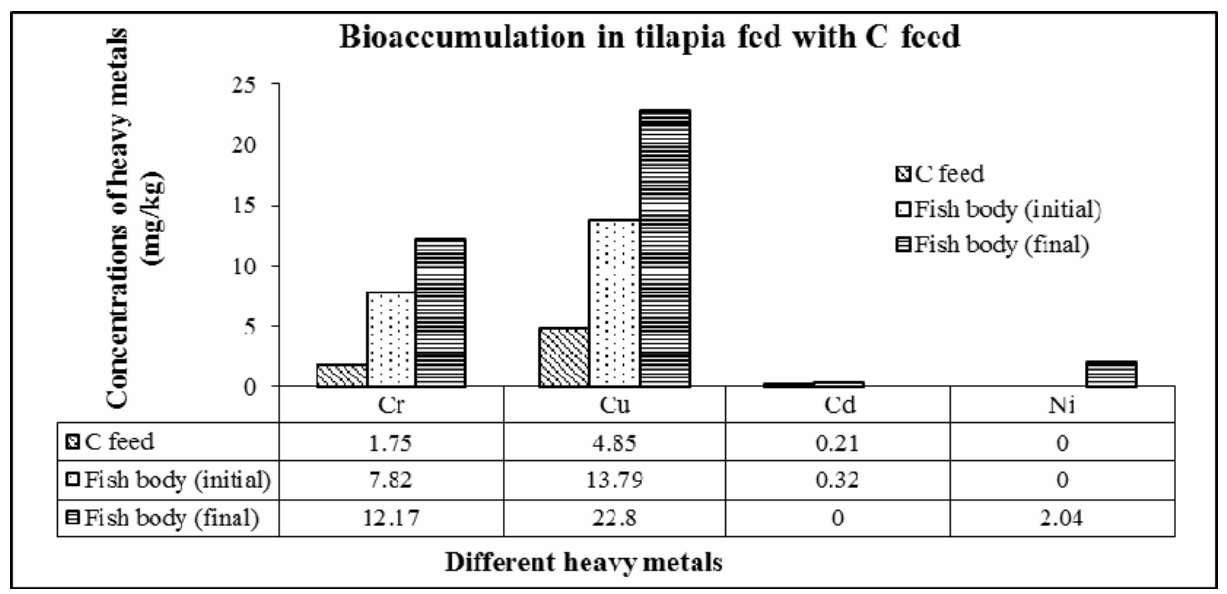

Fig. 11. Comparison of different heavy metals among $\mathrm{C}$ feed, tilapia fingerlings and cultured tilapia fed on $\mathrm{C}$ feed.

In cultured tilapia, the concentration of studied heavy metals was found higher than initial concentration in fish feeds and collected fingerling samples. So bioaccumulation has occurred in cultured fishes from the experimental feeds and water used for culture. Metal levels in cultured fish followed the ranking of $\mathrm{Cu}>\mathrm{Cr}>\mathrm{Ni}>\mathrm{Cd}$. Concentration of $\mathrm{Cu}$ exceeded the tolerable limit in fishes cultured with $\mathrm{S}$ feed. The concentrations of $\mathrm{Ni}$ and $\mathrm{Cd}$ were below the permissible range approved by FAO. Peyghan et al. (2003) pointed out that the liver is the key site for accumulating $\mathrm{Cu}$ and controlling homeostatic whereas Atli and Canli (2011) indicated that kidney displayed the higher capacities on metal accumulation in O. niloticus.

From the above study it can be concluded that the concentrations of heavy metals like chromium, copper, nickel etc. in commercial feeds for tilapia culture in Bangladesh are higher than the permissible limit set by FAO. The presence of the heavy metals in fish feeds could be due to uses of tannery wastes, industrial wastes to produce fish and poultry feeds. The analysis of different heavy metals in cultured tilapia confirms that there is high chance of bioaccumulation in fish tissues by using commercial fish feeds in aquafarms. So this study concludes that fish consumers are exposed to health risks because most of the hatcheries in Bangladesh use those experimental feeds for tilapia culture. There is an urgent need to implement fish consumption guidelines, so as to help fish consumers to reduce exposure to heavy metals. The government should establish laws regarding raw materials used to produce fish feeds and production of fish fingerlings in hatcheries as well. 


\section{References}

Abdel-Baki, A.S., M.A. Dkhil and S. Al-Quraishy. 2011. Bioaccumulation of some heavy metals in tilapia fish relevant to their concentration in water and sediment of Wadi Hanifah, Saudi Arabia. Afr. J. Biotechnol. 10(13): 2541-2547.

ADB (Asian Development Bank). 2005. An impact evaluation of the development of genetically improved farmed Tilapia and their dissemination in selected countries. Operations Evaluation Department, Asian Development Bank, Manila, Philippines.

Alexieva, D., S. Chobanova and A. Ilchev. 2007. Study on the level of heavy metal contamination in feed materials and compound feed for pigs and poultry in Bulgaria. Trakia. J. Sci. 5(2): 61-66.

Atli, G. and M. Canli. 2011. Alterations in ion levels of freshwater fish Oreochromis niloticus following acute and chronic exposure to five heavy metals. Turk. J. Zool. 35(5): 725-736.

Chi, Q.Q., G.W. Zhu and L. Alan. 2007. Bioaccumulation of heavy metals in fishes from Taihu Lake, China. J. Environ. Sci. 19(12): 1500-1504.

FAO, 1983. Compilation of legal limits for hazardous substances in fish and fishery products. FAO Fisheries Circular No. 764; Food and Agricultural Organization of the United Nations, Rome. pp. 102.

Hawkes, S.J. 1997. What is a “Heavy Metals”?. J. Chem. Educ. 74(11): 1374.

Hossain, A.M.M.M., T. Monir, A.M.R. Ul-Haque, M.A.I Kazi, M.S. Islam and S.F. Elahi. 2007. Heavy metal concentration in tannery solid wastes used as poultry feed and the ecotoxicological consequences. Bangladesh J. Sci. Ind. Res. 42: 397-416.

Huq, S.M.I. and M.D. Alam. 2005. A handbook on analysis of soil, plant and water. Bangladesh-Australia Centre for Environmental Research (BACER-DU), University of Dhaka, Bangladesh. pp. 1-246.

Kotze, P., H.H. Preez and J.H. Vuren. 1999. Bioaccumulation of copper and zinc in Oreochromis mossambicus and Clarias gariepinus, from the Olifants River, Mpumalanga, South Africa. Water SA. 25(1): 99-110.

Mansour, S.A. and M.M. Sidky. 2002. Ecotoxicological studies. 3. Heavy metals contaminating water and fish from Fayoum Governorate, Egypt. Food Chem. 78(1): 15-22.

Mohamed, F.A.S. 2008. Bioaccumulation of selected metals and histopathological alterations in tissues of Oreochromis niloticus and Lates niloticus from Lake Nasser, Egypt. Global Veterinaria 2(4): 205-218.

Morais, S., F.G. Costa and M.L. Pereira. 2012. Heavy metals and human health. In: Environmental healthemerging issues and practice. J. Oosthuizen (ed.), InTech China. pp. 227-246

Nussey, G. 2000. Bioaccumulation of chromium, manganese, nickel and lead in the tissues of the moggel, Labeo umbratus (Cyprinidae), from Witbank Dam, Mpumalanga. Water SA. 26(2): 269-284.

Peyghan, R., M. Razijalaly, M. Baiat and A. Rasekh. 2003. Study of bioaccumulation of copper in liver and muscle of common carp Cyprinus carpio after copper sulfate bath. Aquacult. Int. 11: 597-604.

Rahman, M.S., A.H. Molla, N. Saha and A. Rahman. 2012. Study on heavy metals levels and its risk assessment in some edible fishes from Bangshi River, Savar, Dhaka, Bangladesh. Food Chem. 134(4):1847-1854.

Saleh, Y.S. and M.S. Marie. 2014. Assessment of metal contamination in water, sediment, and tissues of Arius thalassinus fish from the Red Sea coast of Yemen and the potential human risk assessment. Environ. Sci. Pollut. Res. 22: 5481-5490.

Streit, B. 1998. Bioaccumulation of contaminants in fish. In: Fish Ecotoxicology. T. Braunbeck, D.E. Hinton and B. Streit (eds.), Birkhauser Verlag Basel, Switzerland. pp. 353-387.

Wepener, W., J.H.J. Van Vuren and H.H. Du Preez. 2001. Uptake and distribution of a copper, iron and zinc mixture in gill, liver and plasma of a freshwater Teleost, Tilapia sparrmanii. Water SA: 27(1): 99-108. 